Taylor \& Francis Group Ltd

\title{
SOCIAL SUPPORT NETWORKS IN IMPOVERISHED EUROPEAN \\ NEIGHBOURHOODS
}

Case studies from Italy and Ireland

\section{Manuela Olagnero}

Dipartimento di Scienze Sociali, University of Turin, Torino, Italia

\section{Antonella Meo}

Department of Social Sciences, University of Turin, Turin, Italy

\section{Mary P. Corcoran}

Department of Sociology, National University of Ireland, Maynooth, Ireland

ABSTRACT: This paper examines the extent to which families living in precariousness in contemporary European cities draw on social support as a key resource in their struggle against poverty. The comparative observations and analysis presented draw on national level survey data as well as local level qualitative data collected in selected European neighbourhoods, under the auspices of the BETWIXT project. ${ }^{1}$ More specifically, our analysis focuses on the active modes and mechanisms for requesting and providing solidarity and support at times of familial crisis. The comparison of the Irish and Italian experiences illuminates the persistent involvement of households in informal support provision, even as family structures alter and welfare regimes change. We demonstrate the dynamics underlying the phenomenon of social support among precarious families living in deprived urban areas in the cities of Dublin and Turin. We address the dialectics between agency and structural constraint by examining whether or not family and/or social support networks are reinforced or further weakened by factors such as economic hardship, unemployment, and neighbourhood dereliction. We conclude that the effects of precariousness are multiple and contradictory: precariousness can create anomie and individualisation but it can also act as a spur to greater community cohesion. Such cohesion can also be expressed

1. Targeted Socio-Economic Research (TSER) BETWIXT project: 'Between Integration and Exclusion: a comparative study in the local dynamics of precariousness and resistance to exclusion in local contexts' 1998-2001. BETWIXT participants included: Helsinki, Finland; Tolouse, France; London, Great Britain; Dublin, Ireland; Turin, Italy; Lisbon, Portugal; and Umea, Sweden. 


\section{EUROPEAN SOCIETIES}

in terms of heightened social divisions along ethnic lines (the case in Aurora, Turin) and class lines (the case in Kilmainham, Dublin).

Key words: social support; precariousness; women; neighbourhood; social networks

\section{Social provision in Italy and Ireland: differences and similarities}

There are both differences and similarities between Italy and Ireland with respect to the diffusion and articulation of the social support model, and its efficacy in the struggle against poverty. Comparisons can be made on the basis of observable conditions at different levels in a number of domains: the resources available from family, welfare intervention, mutual help organisations, and individual initiative.

Even though both countries show strong involvement of women in caregiving duties, there are differences in the background conditions of family obligations: different occupational regimes, different family cultures, different amounts of resources coming from neighbourhood networks and welfare regimes. The Italian welfare system has developed in a form that is strictly subsidiary and residual to family organisation and social networks. On the one hand, the family constitutes the place of recomposition of income and public transfers, and of intra-family and intergenerational redistribution of resources. Access to social assistance is statutorily based on the principle that help should be supplied primarily by the family of origin and kin. On the other hand, a rigid gender division of labour, strong intergenerational ties and kinship solidarity contribute significantly to the unpaid care of children, older people and disabled.

Italy lacks a true family policy, even though various fragmentary and sometimes contradictory measures do exist, particularly in the fiscal and general social regimes. The Italian welfare state, especially in the sectors concerned with the fight against poverty and social exclusion, displays a set of characteristics that in some ways weaken its ability to provide social protection for all categories of people. The system demonstrates a high level of selectivity, a weak role for the State with respect to both the family and the labour market, and a clear preference for occupational status as a requirement for entitlement to social rights. Taken together these features contribute to leaving certain categories of people with minimal social protection (Meo et al. 2001). Support from welfare is, in any case, almost always short-term and is often insufficient unless the beneficiary has a family network to fall back on.

Unemployed people and lone parents are two exemplary categories of recipients within a selective and sometimes 'sub-protective' welfare regime (Duncan and Paugam 2000). Unemployment benefit in Italy is 
contributory-based. In other words, it excludes all young people (and others as well) who are looking for a job for the first time or after a period out of the labour market. This is particularly significant because the Italian unemployment pattern features a high incidence of joblessness among young people. ${ }^{2}$ Lone parents, though recently recognised and supported as a disadvantaged family type, find themselves at different periods of their lives having to turn to the family for help. In such instances, the family proves indispensable (see Bimbi 2000; Meo et al. 2001). Often volunteer associations fill in the gaps left by municipal welfare, but their efficacy depends on the presence of well-rooted civic culture and political participation.

The welfare regime in Ireland may be characterised as a liberal marketoriented system. Peillon (2001) has noted that the Irish welfare regime experienced its most dramatic development in the 1970s, when provision outstripped that of other peripheral European countries. However, the welfare effort peaked in the 1980s and stabilised thereafter. Indeed, the boom years of the 1990s actually coincided with a decline in social protection expenditure as a percentage of GDP. ${ }^{3}$ Despite a commitment to a rights based social insurance system, the Irish welfare regime remains dualistic. Means-tested benefits continue to play a central role in social provision. Social welfare payments have not kept pace with improvements in the standard of living over the 1990s (although they have increased by more than inflation) with the result that those relying on these payments are most likely to fall into relative income poverty (CORI, Justice Commission Briefing 2002). Households headed by a person working full-time in the home are the largest single group living in poverty, followed by households headed up by a retired person. Both household types are heavily dependent on welfare intervention. Research has concluded that the state's welfare regime has done relatively little to reduce the marked social inequalities which have long characterised Irish society (Breen et al. 1990; Breen and Whelan 1992; Fahey 1999a,b). Nevertheless, a system of welfare provision, particularly directed at poor families, has emerged. This consists of a one-parent family payment and a range of family support payments, most of which are means-tested.

2. A very low percentage of unemployed people receive benefits in Italy: only $6.8 \%$, against $70.5 \%$ in Germany and $45 \%$ in France (see Table 1.3, Duncan and Paugam 2000).

3. Social protection expenditure as a percentage of GDP stood at $14.1 \%$ in 2000 (down from $20.3 \%$ ten years earlier) while in Italy expenditure was $25.2 \%$ in 2000 , virtually unchanged from the figure of $24 \%$ in 1990 (Eurostat cited in Peillon, M. Welfare in Ireland: Actors, Resources and strategies. Westport, CT: Praeger, 2001. 


\section{EUROPEAN SOCIETIES}

Up to one-third of all first-time births are to unmarried mothers, although many of these are in stable relationships. The increasing number of lone parents in Ireland has meant a concomitant rise in social welfare spending. Policy makers, concerned about fomenting a 'dependency culture' have been trying to balance the need and desire for young mothers to care for their children full-time during the formative years, against the aspiration to help young women into jobs that will make them independent of the welfare system. ${ }^{4}$ As in Italy, there are in-built assumptions in the welfare code that family support structures are present. For example, with regard to lone parents, there is an assumption that they will continue to live in the family home until the age of 18 years. They may not apply for social housing in their own right until they reach this age. Furthermore, there is an assumption underlying back-to-work and targeted education programmes that a relative, a neighbour or a friend will provide informal childcare as there is no state provision, and only a small amount of grant aid, available for childcare. ${ }^{5}$

In both countries, therefore, it is clear that state provision in the form of welfare payments frequently does not provide enough for people to live on. Additional mechanisms of support must be sourced elsewhere.

\section{The gender division of labour in social support provision}

In this article we refer to social support in terms of informal (not professional or institutional) resources flowing along social bonds, and having the functions of instrumental or moral help, information and companionship. Support implies 'social transactions whose aim, as perceived by the receiver or as intended by the supplier, is to assist the individual in coping in everyday life and particularly as a response to critical situations' (Thoits 1984; Pearlin 1985; Pierce et al. 1990: 173). Most analysts concur that social support is an inherent part of the relational fabric rooted in social relationships and exchanged through them (Meo 1999). So defined, social support can be considered as a specific form of social capital, as an 'appropriable social structure', not belonging to individuals but which 'individuals can use for their own strategies' (Coleman 1990). Following Walker, Wassermann and Wellman we specify social support as a ' $\ldots$ general resource put at the disposition of an

4. See for example the Reviem of the One-Parent Family Payment. Dublin: Department of Social, Community and Family Affairs, 2000.

5. In proportionate terms, lone parents in Ireland have been found to be more reliant on unpaid relatives for their childcare arrangements than two-parent families, (Quarterly National Household Survey-Childcare, Fourth Quarter, 2002). 
individual by his network of kin, friends and acquaintances, to help him cope with both everyday problems and moments of crisis ...' (1993: 71).

To explore the concept of social support we focus on the family, both as a context of specialised functions and interactions of roles, and as a unit in itself for providing and receiving help. ECHP indicators make it possible to compare ways of exchanging social support inside and outside families among different European countries. They also provide information about general background conditions that can explain the existence and form of social support in different contexts. The most important background condition is participation in the labour market. Italy has the lowest presence of women in the labour market, and the widest occupational gender gap, in the European Community (see Boje and Halskov 2001; source: EC, Employment in Europe 2000). This distinction is partly due to the relative scarcity of part-time jobs in Italy. This fact, together with the inadequacy of fiscal and social policies devoted to the family, explains the difficulty of reconciling work and family for Italian women (Saraceno 2003). In Ireland, in contrast, women's participation in the labour force has continued its upward trend since the 1980 s, rising to $48 \%$ of all women aged 15 and above in 2001. This trend has also brought new pressures to bear in terms of work life strategies and access to social support (Gray et al. 2003).

Care giving is the principal, if not the only form, of social support. An important indicator of the kinds of help exchanged within families is 'unpaid time spent looking after children' (Eurostat 1997; Boje and Halskov 2001). According to this indicator, ${ }^{6}$ Italian and Irish women are heavily involved in care-giving compared to men (around 14-16 hours per week for women in both Italy and Ireland, contrasting with the low commitment of men: an average of 3.7 hours per week in Italy and 4.1 hours in Ireland). National statistics also show that in Italy help is concentrated on, though not limited to, childcare and assistance to older people and, in the second instance, to domestic activities (Istat 2000). Women are more involved than men in informal support networks, and they dedicate more time to support activities than men do. ${ }^{7}$ The heaviest burden of responsibility is carried by women with small children: this increases with the number of children and does not appear to be limited to one particular cohort.

6. The observation concerns both children under 16 years and children under 5 years. The results do not vary substantially.

7. Female work constitutes two-thirds of the work supplied (Istat 1999). A total of 54\% of married women work more than 60 hours a week, between domestic tasks and jobs outside the home, compared to only $15 \%$ of employed men (Istat 2000). 


\section{EUROPEAN SOCIETIES}

Moreover Italy, together with Greece, is quite distinct from the rest of Europe in that $29 \%$ of childcare is also performed by grandmothers (Eurostat 1997). More recent research on childcare arrangements in Ireland, however, points to a substantial level of reliance on unpaid relatives among families with pre-school and school-going children (QNHS 2002). ${ }^{8}$ Childcare arrangements for working mothers are frequently made on an informal basis with considerable reliance on the support of family, neighbours and friends. There is little recourse in either Italy or Ireland to commercially provided services, which seem to represent a solution only when solidarity networks fail. ${ }^{9}$

Taking account of the variables considered, Italy and Ireland are similar with regard to family obligations and the strong involvement of women in care-giving. However, important differences in relation to role definition may be observed between the two countries. In Italy remaining at home is often perceived as a constraint: $32 \%$ of Italian housewives express dissatisfaction with their confinement to home. This figure is similar to that recorded in Portugal and Greece, but markedly different to the case in Ireland, where only $5 \%$ of housewives report feeling dissatisfied (ECHP 1998). Irish women who are not in the workforce, unlike their Italian counterparts, are significantly happier with a domestic role. Indeed, research demonstrates that only $6 \%$ of Irish women engaged in 'home duties' are looking for work each year (Russell et al. 2002: 31). Although there are increasingly numbers of married women in the workforce, the Irish value system generally is supportive of 'stay-at-home' mothers. The special position of the family in Irish society and the role of women in the

8. There are few studies that address the childcare practices of working parents in Ireland. A total of $42.5 \%$ of all families with pre-school children, and $25.5 \%$ of families with school going children regularly rely on non-parental childcare arrangements for minding children during normal working hours. Of families with pre-school children availing of childcare, almost one-third $(31.5 \%)$ rely on unpaid relatives. The reliance on unpaid relatives is somewhat greater for minding school going children, where $46 \%$ of families seeking care for such children, rely on unpaid relatives (Quarterly National Household Survey-Childcare, Fourth Quarter, 2002). Similarly, a survey commissioned by the Irish Congress for Trade Unions, indicates that some $43.2 \%$ of all childcare service users rely on 'informally' paid childcare services. The largest group in the sample, $24.4 \%$ rely on informally paid relative, friend or neighbour minding in their own home, while a further $22 \%$ rely on using non-paid child care services such as an unpaid family member, unpaid relative, friend or neighbour (Irish Congress of Trade Unions, Identifying Members Childcare Needs, 2002).

9. In 1998 only $8.8 \%$ of families in Italy resorted to paid services (Istat 2000); the corresponding figure for Ireland was 7.5\% (Quarterly National Household Survey 1999-2000). 
home is underlined in the Constitution, and was re-affirmed in the Report of the Commission on the Family in 1998.

The Italian family is based on a model of proximity ${ }^{10}$ that makes feasible the exchange of social support through childcare provisions within the extended family. In contrast, the Irish family model is increasingly dispersed, making it more and more difficult for young families to avail themselves of informal child care services from their families. In the absence of regulated state provision, this acts as a barrier to labour market participation.

\section{Role of social support in impoverished European neighbourhoods}

Having reviewed the aggregate data from both countries on the significance of social support provision, we now present two case studies of the ways in which social support is conceptualised, manifested and reproduced in the everyday lives of residents in precarious neighbourhoods. Specifically, we examine the extent to which families living in precariousness in Dublin and Turin draw on social support as a key resource in their struggle against poverty. Precariousness refers to an intermediate state of detachment lying on a continuum between social integration and social exclusion. The concept is dynamic rather than static, in that precariousness presages a possible descent into social exclusion or the reverse, an ascent into a position of integration. In addition, the BETWIXT approach extends the term to apply to neighbourhoods. The goal of the project was to identify precarious households within precarious neighbourhoods and examine the interaction between neighbourhood and household dimensions of precariousness (Fahey 2000). Hence, our focus was not on the internal dynamics of support within any given household, but rather on the interactive relationships between members of the household and family and kin in the neighbourhood. A two-pronged approach to data collection was adopted: first, researchers mapped each of the participating cities in terms of the extent and degree of urban social inequality and spatial segregation. Second, city research teams selected a single neighbourhood within their remit, which exhibited levels of precariousness as measured by relative income levels and unemployment rates. Each of the six case study neighbourhoods was studied through the combined techniques of field research, interviews with key informants and life

10. In 1997 the percentage of married Italians aged 18-64 who lived near their mother was $34 \%$ of those whose mother was still living: $3 \%$ in the same home, $9.8 \%$ in the same building and $24.7 \%$ within a kilometre (Istat 1999). 


\section{EUROPEAN SOCIETIES}

history interviews with 27 householders. Each city team analysed the qualitative data and produced an ethnographic account of the neighbourhood organised around a set of key themes. At this stage, it was possible to compare and contrast the experiences in the participating cities, and to produce an overview (Bertaux et al. 2002). The authors then re-visited our respective datasets, and through a process of constant comparison began to develop our analysis of the social support function further. Here we draw on the life history interviews conducted in Kilmainham, Dublin, and Aurora, Turin, in order to explain the reliance on social support mechanisms as an important resource employed by those living in precariousness. ${ }^{11}$

Unemployment and general economic precariousness, more prevalent among the lower socio-economic groups, are associated not only with loss of social ties and networks but also with a progressive impoverishment of these networks. Families continue to be reference points, but they are less supportive in terms of material help. However, compensating for the fragility of support networks among the lowest social classes, there is a greater commitment in terms of actual number of hours of help given. Hence, the precarious position of those living in poor neighbourhoods, is tempered to some extent by the strong sense of social and community solidarity that is anchored in residents' everyday social relations and practices. Socio-familial bonds are crucial for maintaining quality of life. In the neighbourhoods of Aurora in Turin and Kilmainham in Dublin, we observed a social network configuration that social analysts have suggested is necessary to thrive in respect of health for children, adults and frail elderly people (Perri 1997: 22). On the other hand, these neighbourhoods lack the 'weak ties' or 'bridging and linking capital' ${ }^{12}$ that facilitate access to educational and employment opportunities. Let us now examine the case study neighbourhoods in greater detail.

11. Aurora, a neighbourhood just northeast of the city centre of Turin, shows a high degree of deprivation, emerging on the basis of Principal Component-Analysis. This analysis, based on 25 variables taken for 1991 census data, has shown the presence of three risk factors (named: working poor, marginality, ageing) resulting from the spatial correlation of the variables. In Aurora the three risk factors show scores above the mean (see Olagnero with Barbera and Nazio, Turin in the nineties in J. Flately and S. McIntosh (eds), Social Inequality and spatial segregation in seven European cities, London Research Centre, 2000).

12. An important distinction is made in the literature between different types of social contact: bonding (to people like you for getting by in life); bridging (to people not like you for getting on in life); and linking (to people at a different step in the social ladder for obtaining access to resources and knowledge), see NESF Report on Social Capital (2003: 4). 
We can hypothesise that industrial decline affects not only the economic condition of households, but also their social means of coping with poverty and precariousness. The neighbourhoods of Aurora, in Turin, and Kilmainham, in Dublin, are both shaped by industrial decline, but they differ in terms of the degree of social segregation ${ }^{13}$ of the poor.

At the outset of the study city maps of poverty were constructed from available census and registration data. This provided a picture of the spatial distribution of precariousness and poverty for the cities at district level. To do this we used such indicators as rates of unemployment, youth employment and the proportion of ethnic minorities living in the area. We looked at trends over time and the patterning of poverty over city territory. Dublin city was the most segregated of the cities, while Turin was at an intermediate level (Berteaux et al. 2002: 9).

Kilmainham is fairly typical of a formerly industrial neighbourhood that since the 1970s has gone into decline. De-industrialisation meant the closure and relocation of many places of employment. No serious attempts were made by the state to halt the progressive decline by directing new investment into the neighbourhood. A social housing project built at the time became one of the most notorious in the city because of its endemic heroin problem. The area became synonymous with the drug problem, resulting in further dis-investment and dereliction. Quality of life declined and this hardened the existing divisions within the neighbourhood, mainly between private homeowners and social housing tenants. Now the neighbourhood is changing again. The social housing that caused many of the problems is being redeveloped under the auspices of a comprehensive integrated area plan. The pressure to provide more homes in Dublin has enhanced the profile of Kilmainham, because of its relative maturity and proximity to the city centre. Thus, all available sites, many of which were formerly occupied by industry, are being developed for private residential accommodation. If there is a threat to the social fabric it is seen as coming from the influx of gentrifies on the one hand, who are not predisposed to participate in traditional community activities, and on the other hand, the residual effects of an area beset by problems associated with a drug economy and culture. Thus, in so far as polarisation occurs in the neighbourhood it is principally formed around social class, and most specifically, housing tenure. A sharp division is observable between home owners and those who rent housing from the local authority.

13. In the quantitative step of comparative study of Betwixt cities, social segregation was calculated through a dissimilarity index (see Flatley and McIntosh 2000). 


\section{EUROPEAN SOCIETIES}

Aurora has a much lower degree of segregation than Kilmainham. ${ }^{14}$ However, in the city of Turin the general tendency is for segregation to increase over time (Bertaux et al. 2002). The increasing degree of segregation does not favour any sense of belonging to the community. On the contrary, there is a strong polarisation between long-time residents and newcomers. It is known that conflicts over ethnicity and value differences do not produce negotiable positions, unlike class conflicts (Hirshman 1997). They tend therefore to weaken intermediate social structures and increase the risk of total disaffiliation from the neighbourhood, (Dubet 1995). These features are deeply rooted in the immigration and industrial history of Little Aurora (Meo and Olagnero 2000). In an earlier period, industrialisation attracted people of similar backgrounds, mainly young immigrants from southern Italy who came to work in the large factories. In the 1990s the industrial crisis damaged the underpinnings of social identity: the community of work and shared cultural origins. Some residents moved away; those who remained are now witnessing a new wave of immigration, which they perceive as a threat to their safety and well being. Nevertheless, in a certain way the collective memories of the 'good old days' in the neighbourhood act as a bulwark against disaffiliation and anonymity.

\section{Social support and everyday life in Aurora, Turin}

Several research studies, and some conducted in Turin, ${ }^{15}$ demonstrate that the social classes that are poorer in human and social capital are also less capable of soliciting and obtaining help. ${ }^{16}$ We do not know whether this mixture of risks existing on the same territory and identified through quantitative analysis, generates a social burden or if the various risk

14. In Turin, in the 1990s this low level of segregation had a particular meaning of territorial diffusion of poverty risk. In the decade from 1981 to 1991 the relative position of deprived and privileged areas was rooted in space: the deprived areas located to the north and south of the city centre appeared to drag adjacent areas downwards in a sort of 'stain' effect (see Olagnero et al. 2000).

15. Survey data reveals that blue collar workers and their families get less help than white collars and professionals (Negri and Olagnero 2001). Moreover, a survey in Turin on adult families using public housing demonstrated that the condition of relative economic poverty (measured by the Standard of International Poverty Line) does not significantly raise the threshold of help received compared to 'non-poor' families, nor does it greatly modify the frequency of informal help obtained from outside.

16. These data are consistent with some findings of European studies exploring the links between precariousness and social isolation (see Paugam and Russell 2000). 
categories lead separate lives, at most causing fracture and discontinuity in the district. We do know that we are dealing not only with individual or family risk, but risk involving the whole district as a social context. From the qualitative (ethnographic) step of analysis we obtained more information about coping strategies and feelings. The most common reaction to 'decline' in Aurora (and to the feeling of not being included in urban renovation policies), is a kind of familial closure, a turning inward of the family unit to seek refuge in private life. (This strategy was also observable in Kilmanham as we shall see later.) Yet these behaviours do not translate into plans to move away. The neighbourhood is a trap, but at the same time an ultimate protection against total disaffiliation. The closing of small neighbourhood shops, parallel with the opening of large supermarkets and ethnic shops, is a physical sign of the break with the past:

Whereas in the past the little local shops were a point of reference for everybody - you met at the bakery and had a chat, you knew each other and said hello - in the last 3 or 4 years these shops have disappeared and there's less opportunity to meet ... (Respondent Bt, Aurora)

This process reinforces the sense of closure and encirclement, especially among the elderly. Indeed, the interviewees conduct their lives within a small part of the urban territory, taking little advantage of the opportunities which the city offers. They spend their time between work and home; there is little social interaction, partly because the district offers few opportunities but also because most families are constrained by financial difficulties and have to limit their spending. Only a small number of interviewees were actively involved in the school and parish. Mobility within the Aurora neighbourhood is strongly affected by the presence of foreign immigrants, who are perceived as a threat. Some of our interviewees say they sometimes change their usual routes to avoid streets heavily frequented by foreigners. The issue seems to go beyond the problem of crime: diversity itself is frightening (Miceli 1999).

I'm not a racist, but these foreigners are really crude, for example at night they break their beer bottles on the ground and if I take the children out they risk getting cut ... (Respondent Au, Aurora)

Lack of security (in the neighbourhood or building) is a leitmotif of deprivation for the interviewees in Aurora, but few thinks seriously of moving elsewhere, as moving costs are generally very high. Those who have managed to move went only a few blocks away from the area, 


\section{EUROPEAN SOCIETIES}

which they considered dangerous. The concurrence of new cultures and identities gives rise to new problems in a culturally deprived context:

At my children's school there are some foreign children, and they seem wellbehaved. But it bothers me that there are so many foreign children of other religions; it seems like we're expected to adapt to them, so we no longer have festivals where we celebrate the Baby Jesus. We who live in Italy have to give up our customs for them, whereas in my opinion they should be the ones to adapt to our culture and our religion ... (Respondent Am, Aurora)

The ways of reacting to precariousness are different but not mutually exclusive (family, social services) (see Meo and Olagnero 2001). The help offered by a family member or relative in finding a temporary job is not enough to resolve the economic problems of a family with one or two children. For example, one 22-year-old respondent, with a husband and two small children, was temporarily staying with a family member but this did not resolve the constant struggle against the possibility of eviction. Individuals and families are continually mobilised to construct a patchwork of help measures, and at the same time to conceal them from the social services, which apply means tests when deciding whether or not to grant economic subsidies. Those who count solely or predominantly on family capacities and resources are usually those confronting 'ordinary' problems of improving their living standard or consolidating their position with a view to the future. However, faced with a serious health problem or income shortage, a household must employ a double strategy: mobilising internal resources but turning as well to the social services or other private and volunteer organisations. In the case of several lone mothers, external mobilisation sometimes involves friends or neighbours.

Only when the family of origin is very stable and well rooted can there be long-term help. Some couples interviewed have succeeded in their efforts to avoid poverty because of their ability and willingness to save; sometimes they have even managed to buy their own home and now have enough to help their children. For example, one respondent in her $60 \mathrm{~s}$, who is married and is a retired nurse, is raising her grandson, the child of her handicapped daughter. For a long time, this woman also cared for another child, the granddaughter of a daughter-in-law who works. As networks tend to centre on the family (nuclear or extended), social networks outside the family are generally small, with relatively few social contacts among neighbours or through associations and free-time activities. Overall, we found that reliance on the family is relatively limited by a number of constraints: the difficult financial situations of the 
parents of the respondents (as precariousness and poverty are often embedded in a family's history); the unpredictable role of siblings ${ }^{17}$; and the seriousness of respondents' needs. A stressful event, especially when unforeseen, undermines the individual or household's capacity to master the new situation without support (see Meo and Olagnero 2001).

\section{Family networks: straddling support and sociability}

Even if the family cannot provide adequate economic support, it nevertheless is perceived as the primary point of reference in satisfying the needs of sociability and solidarity. Family and kin represent the heart of individual and family sociability (meeting together periodically for a meal, visiting one another often, doing the daily shopping together) for people who have few resources to spend in free time activities outside the family and who are always trying to minimise expenses. Therefore, family members are the most important friends:

I don't like friendships, my friends are my father and my mother ... (Respondent L, Aurora)

Access to nearby family is a resource. One of our Aurora interviewees, after being widowed, re-established ties with her family of origin and moved back to Turin after years of absence, uprooting herself from the town where she had been living. In many cases in which the family of origin lives in Turin in the same area (Aurora), contacts are frequent, and many women do their shopping with their mother or sisters-in-law:

I get together with my sisters-in-law, sometimes we go shopping together, at the weekend we all go to Colletta Park or to a hypermarket. My husband's brothers had their children during the same years, and counting our kids there are nine cousins in all ... (Respondent Am, Aurora)

No, we don't see many other people, we say good morning and good evening to our neighbours but we don't like to bother other people; we've made friends with the parents of a few of our kids' schoolmates but we've never seen them at home, we prefer to relax together as a family ... (Respondent F, Aurora)

17. Sometimes there are only weak familial ties because migration often separates families and people then have to fend for themselves. Sometimes siblings are present, supportive and active but only if they live locally and are not themselves squeezed by precarity. 


\section{EUROPEAN SOCIETIES}

Within the family the most supportive relationship (in terms both of emotional and material aid), is between mother and children. This general observation is borne out among the inhabitants of Aurora, where the role of men is almost exclusively limited to providing family income. The women interviewed generally have smaller social networks than the men do. In many cases they don't work outside the home and in complaining about this situation they also complain about the difficulty of making new friends. Often the husband already lived in the district before marriage, and when the wife arrived she didn't know anybody. In the precarious neighbourhood where adult (married) women are often inactive in the labour market $^{18}$ female sociability is territorially based, unlike male sociability which is primarily structured through networks created on the job. The absence of work is in fact a handicap in the creation of social networks.

It's hard to find a job, partly because of my age; I'm 33 and when they hear I'm married with two children and over 30, they aren't interested. I got married at 20 and had kids right away. When I was young, after finishing middle school, I did odd jobs in local shops, and some house cleaning, but nothing regular. When the children were small I never considered leaving them to go to work, I figured I would raise them myself and when they were bigger I would see, but now it's too late. I'm glad I raised them but I want something for myself, to get me out from these four walls ... (Respondent Am, Aurora)

However, it must be recognised that children offer these women opportunities to create local social networks, a phenomenon which is described in the literature (Fischer 1982; Ishii-Kuntz and Seccombe 1989; Wall et al. 2001). Having children increases adult women's concern with safety, recreational opportunities and local school and although many women complain of feeling isolated when they are first married, after the children are born the situation improves, as there are opportunities to meet other mothers. Some of the interviewees are parent representatives at their children's schools, a public role which they have created over the years.

When I was first married I was always at home, I went to buy the bread and then returned home; but when my older son started going to nursery school I began to meet other mothers, because you end up talking about your children at the public garden ... (Respondent Am, Aurora)

18. Although the unemployment rate for Italian women aged 30-45 has greatly diminished since the end of the 1970s, it remains quite high compared to the rate for men (around 45\% against no more than 13\%) (Istat 2000). 
Women with children who are particularly sensitive to problems of public safety, find many reasons for fear and suspicion in severely deprived neighbourhoods. They emphasise the risks of living in the area (for themselves and their children), and complain of feeling constrained in their freedom to move around and make use of the urban space. Older women are more concerned with the accessibility of shops and services, and generally evaluate the neighbourhood positively. The two groups (the women with children and older women) can be thought of as territorial guardians or keepers of territory.

Among the younger women, often unemployed or employed in odd jobs, we find what might be called agents of community. It is the women, rather than men, who, in spite of having only sporadic relations with neighbours, weak family networks and turbulent life histories, find in institutions the key to building a social network. Personalised relations with frontline staff in social services delivered at neighbourhood level provide access to network within the community. ${ }^{19}$ There appears to be a mechanism at work (already illustrated with regard to role transitions such as widowhood and divorce: Hirsh and Jolly 1984: 43) whereby developing intensified involvement outside the family sphere can be a crucial resource for successful social adaptation. In this way a strong territorial rooting is created.

A different key role is played by the school, which enjoys an extraordinary degree of trust among the more deprived social categories in Aurora. For the poorest families, school is a means of socialisation and social integration, more than a means for gaining social mobility, as the following quotation from a 36-year-old, lone parent illustrates:

... I always tell my children they should continue with their studies. I tell them they'll miss those days, after they finish school. You miss school, because it's a happy place ... Yes, when I see my son's teacher around we chat, and I have a really good rapport with the nursery school teachers, in fact I've been to their homes. My son's godmother was a teacher at the nursery school ... she didn't have children of her own and she was fond of my daughter Nerea. She would come and get her, take her to her house, take her to the riding stables ... And I've always been friendly with everyone at the school, partly because I'm ... I like to joke around, I'm sociable and so are my children ... I don't feel any

19. The rapport with social services is often personalised, yet the strong stigma attached to receiving public assistance frequently prevents these relationships from becoming friendly (Negri and Saraceno 1999). In Ireland, the St. Vincent De Paul, a charitable organisation supplement public provision with material and financial support to families in need. To rely on such charitable help, however, is frequently stigmatised within the community as evidence that the recipient has become virtually destitute. 


\section{EUROPEAN SOCIETIES}

nostalgia for the place in the country where I was born ... I like to go around, have contact with people, see how they do things and how they think, that's what I really like ... as long as they're respectable people. (Respondent, B, Aurora)

Mothers of school-age children may achieve social recognition and build a social network through the school. Indeed, we found that in Aurora it is possible through school to extend limited participation into a stronger sense of social belonging and sense of citizenship (Carter 1985).

\section{Social support and everyday life in Kilmainham, Dublin}

There are both similarities and differences between the experiences of residents of Kilmainham in Dublin and those of Aurora in Turin. While we have found evidence of bonding social capital - personal linkages that help people to get on in life - there is little evidence of bridging and linking social capital. Social networks tend to be parochial, and the ingroup solidarity they promote impedes a reaching out to potential networks beyond the neighbourhood.

Like their counterparts in Aurora, old-timers in Kilmainham reminisce fondly about the old days when the neighbourhood was characterised by a strongly integrated sense of community predicated on traditional family arrangements, a clear gender division of labour in the household and relatively large families.

It was a very vibrant area then and very united ... It was a lovely place to grow up. We had nothing, I don't mean we needed anything but that was the general thing. There wouldn't have been anyone with a lot of money. Everyone was the same. On this street - one, two, three four houses [in a row] we were like one big family. If one had money we all had money. Everything was shared. Nobody would go without a dinner. (Respondent F, Kilmainhan)

Older residents display a strong sense of emotional rootedness to their local area. This is predicated on a sense of a shared historical past, and feelings of nostalgia often arise from the experience of a lifetime lived almost exclusively within the locale. The neighbourhood's past, and in particular, embedded memories from childhood serve as an important reference point, especially in the context of the neighbourhood undergoing transformation from gentrification (Kilmainham) and increased ethnic diversification (Aurora). When asked to talk about neighbourhood, respondents frequently resorted to elaborating specific memories of how the place used to be - memories of childhood games on the street, 
of kin-like sociability between neighbours, of communality born of a shared hardship (Corcoran 2002). This suggests that high levels of a particular type of social capital sustained these communities in the past. Access to a local support network, and the absence of a sense of relative deprivation, created high levels of informal sociability, underlined by a norm of reciprocity and trust.

The degradation of parts of the neighbourhood through drug use and environmental decline, has forced a turning inwards, with families withdrawing from the wider community and relying more on their own members and immediate neighbours to safeguard their quality of life. ${ }^{20}$ For example, interviewees residing in some social housing blocks in Kilmainham felt themselves to be in a very precarious situation. Antisocial behaviour such as drug dealing and intimidation were widely experienced. Parents had a genuine fear for the safety of their children. As a result many of the mothers to whom we spoke would like to be re-housed elsewhere, if it meant securing a better environment for their children. For them, the norm of trust that exists in other parts of the neighbourhood is absent. It has been replaced by a norm of fear. They feel disaffiliated from their immediate community and the neighbourhood. Their thoughts are of escaping rather than engaging in collaborative community action to alter their social conditions. Residents also reported feeling a loss of control over public space. The issue of security is a major concern:

I wish they'd get the flats sorted out, like starting the upgrading and the security gates but they [local authority] take so long to do anything. I go down and complain to the estate managers and they always say it won't be long now ... but nothing happens so it's no wonder that people get fed up and move. (Respondent L, Kilmainham)

The tone of the interviewees living in these social housing blocks is one of world-weariness. While many have been actively involved at community level in lobbying for change, change seems to come very slowly and cynical disillusionment inevitably sets in. Civic engagement requires time, energy and resources. With an aging population in many parts of the neighbourhood and many more women working either part-time or full-time, dayto-day interactions have decreased. Women have little energy to come home in the evenings and engage in voluntary community work.

20. A recently published study on everyday life in low income families also found that rather than being well integrated into their area, almost half of Dublin-based households, said that they lived in fear of people who lived or operated locally. There was considerable evidence that many adults felt bullied and picked upon locally (see Daly and Leonard 2002). 


\section{EUROPEAN SOCIETIES}

Furthermore, the less available and visible the mothers - the territorial guardians - the lower the possibility of informal socialisation and surveillance of children. Familial closure results, with residents becoming increasingly preoccupied with simply minding their own children, and confining their social activities to their family circle:

My daughter is doing her Leaving Certificate down the road and she has a part-time job in McDonalds. [Daughter was formerly using drugs] She's not bad, she just got in with the wrong bunch around here. You can do your best for them but they don't learn everything at home. That's the main reason I want a house. I just want privacy. I want to be able to close my door and leave it behind and you can't do that in the flats. Not around here anyway. (Respondent I, Kilmainham)

According to Daly and Leonard (2002) in the absence of local support, family relationships are crucial in helping people to keep going when times are tough. In their study of everyday life for low-income families in Ireland, they found a strong sense of families turning inwards, with couples acting as a support for each other or sometimes children for their parents.

Class position and spatial location shape the geographies of childhood, and this is brought into sharp relief in neighbourhoods like Kilmainham and Aurora. The everyday experience of families living in precariousness is proscribed by the desire to better themselves (by aspiring for their children) and their dread of falling further into poverty, delinquency and destitution. There is considerable disillusionment about raising children in risky environments, which threaten to brutalise the child:

I think the days of raising a family in a block of flats is long gone. I mean my Ma had five of us here and other families here at the time had even more kids and that was fine but neighbours now are completely different. Before, neighbours used to watch out for each other. When I was a kid here you had respect for your neighbours and you wouldn't answer back an adult. That's gone now. (Respondent I, Kilmainham)

I didn't send my kids to the local schools. It was a conscious decision. You see my house is situated on the banks of the canal where the drug problem is terrible. I have to protect my children. I see the drug element that is there in the schools ... I chose to take my children out and put them in a different school. It was a hard decision but bringing my children up on my own, it was great to say, 'sure I am living in it, but I don't want them to go to school in it'. It has worked. The boys that would have been a play group with my son would 
be the boys that he would be in school with now, and those boys don't stand a snowball's chance in hell. (Respondent C, Kilmainham)

As in Turin, we found considerable evidence in Kilmainham that residents rely on extended family networks on an ongoing basis. It is not uncommon, for example, for adult children to live close to their parents, or for adult siblings to live close to each other. Even when people leave the area, it is often a temporary measure and they will return at the first opportunity:

An awful lot of families stayed in this neighbourhood and an awful lot of people know each other through family connections in the area. My own brother who lives in Drimnagh [a proximate neighbourhood] still has it in him to live here. $\mathrm{He}$ wishes he was living here. There is some kind of intangible chord, something that draws people back. (Respondent D, Kilmainham)

My family live around the area. My brother lives in the same complex but in another block but I rarely see him. My sister lives opposite in St. Michael's and I am very close to her. I have another sister living in an adjacent area and I see her often as well. The rest of the family live near my $\mathrm{Ma}$ and $\mathrm{Da}$ who are in [nearby] Inchicore. (Respondent H, Kilmainham)

For those parenting alone, accessing job opportunities or further education were highly dependent on the availability of childcare provided by a member of the immediate family, usually the child's grandmother. But while the availability of this kind of informal social support undoubtedly assists the lone parent, it also makes them feel guilty about overdependence on family members. Often they could only afford to return to work by paying their mothers considerably less for childcare than would be the norm were they to use formal childcare services:

I'm nearly 27 years of age. My parents don't need another child living at home and a baby. They're into retirement now and they want their life back I'm sure, but I can't afford to pay rent and pay my mother to mind the baby when I am working, (Respondent U, Kilmainham)

As well as providing practical support in the form of child minding, grandmothers also provide emotional support to their daughters and grandchildren. For some of those living in the blighted areas of the neighbourhood, regular visits to their grandmother's home provide a respite: 


\section{EUROPEAN SOCIETIES}

I see her [daughter's] kids growing up here, I mean they practically live in my place as it is. If I had a house tomorrow, I'd have them with me. (Respondent $\mathrm{X}$, Kilmainham)

A grandmother may exert significant influence on her grandchildren. ${ }^{21}$ Two sisters told of how their grandmother has encouraged them to aspire toward a good education and career:

My nanny [grandmother] puts a fiver by every week for us - me and my sister - to go to college. Every Friday when she gets paid, she'd have on her list like groceries, electricity bill, gas and then she would have Geraldine and Teresa's credit union. (Respondent P, Kilmainham)

By putting aside a portion of her pension into a college saving account, this woman is inculcating a sense of aspiration and possibility in her grandchildren. Here is a classic form of moral and economic support that is sourced inter-generationally. In some instances, long-standing neighbours become surrogate family members, particularly to address the needs of older or infirm residents. In Kilmainham, many older residents without family nearby are fearful of becoming victims of crime. They no longer feel safe on the streets of the neighbourhood. Here younger adult women act as territorial guardians. Good neighbours are relied upon to provide a significant form of social support:

People will tell you that they can't walk up to the village. That it isn't safe. I was getting my neighbours' pensions for them because they couldn't. They were so afraid. They were phoning up the butcher and getting him to deliver the meat. I call into the neighbours on a regular basis and if they are in hospital I will bring up a dinner to them or whatever if they don't like the hospital food. I can see all the children going off to get married, and the old people left behind. It's very sad. (Respondent C, Kilmainham)

There are a lot of differences between the blocks (of flats). That one over there is the best. That's because that's the one that has most of the old neighbours still in it. There's none of the old tenants left in this block. Years ago you had friends on all the balconies and people kept the place clean. When I think of it, it was always the women who kept it clean. The women fight for everything,

21. A recently published study on family dynamics in Ireland has highlighted the importance of the supports provided by the extended family, as well as the intergenerational aspect of family life. The researchers found that the quality of the grandparent relationship, for example, exerts a signficant influence on children and grandchildren (McKeown et al. 2003). 
especially the ones with kids. The men are useless here really and its not like a lot of them work or anything. (Respondent I, Kilmainham)

In Kilmainham in Dublin, children are an important point of contact in the community. A Family Resource Centre operates in the neighbourhood, offering a range of services including a crèche, after school service and an outreach programme for women who may have experienced violence. The Centre also provides community development programmes for women. It is clear in the community of Kilmainham, and indeed in other deprived neighbourhoods in Dublin, that women are the key agents in holding the community together. This raises important questions about the role of men in society. There is a small but growing debate emerging in Irish public policy on the marginalisation of men in poor and deprived communities, (McKeown et al. 1998). Suicide is on the increase among young Irish men, and some ethnographic work done in inner-city neighbourhoods shows that it is primarily women who are gaining from self-development programmes, and who are driving community action (Corcoran 1998; Fahey 1999a). It is possible that young, uneducated men and older unemployed men are becoming more precarious in disadvantaged neighbourhoods. Poverty and its associated difficulties may be less and less a gendered phenomenon as men and women find themselves in equally precarious positions.

Pressure to provide more homes in Dublin has enhanced the profile of Kilmainham, because of its proximity to the city centre. Thus all available sites, many of which were formerly occupied by factories, are being redeveloped as private residential accommodation. The area is also set to benefit from an urban regeneration plan, which will see the demolition of the problematic social housing complex. Old timers worry that there will be little integration, either socially or economically, between the new residents of apartment buildings and the existing community:

The new apartments tend to be surrounded by walls and gates. There is a big emphasis on privacy and that creates barriers. You can't create contacts across gates. People isolate themselves inside the gates; they create their own patch and don't want to get involved. This is different to having openness, an awareness that you are living among different groups, and different age groups. On this estate you cannot assume that you are living beside people who are young. Two or three doors up there could be an elderly person or couple. There are lots of ages living around here but yet everybody can kind of interact. Some of the houses are being bought by people who are anonymous, who don't want to know or get involved and that is offensive to people. (Respondent A, Kilmainham) 


\section{EUROPEAN SOCIETIES}

Residents also recognise that gentrification pushes housing prices beyond the reach of the local population, leading to displacement:

The prices of the new apartments are outrageous. People have to buy outside the area now. It has to have an impact. A couple would have to work, and wouldn't be able to have children for years. And then they can't live in the neighbourhood they grew up in because they can't afford it. They're moving out and new people are moving in. Couples are moving out and leaving their parents in the area. Who is looking after them? (Respondent C, Kilmainham)

Social support provision, through networks of friends and kin-like ties with neighbours, are being eroded through the structural changes taking place in the neighbourhood. Such provision has in the past played an important role in supporting families, encouraging collective action, and fostering links across the generations. Volunteering, informal sociability and the norms of trust and reciprocity were all hallmarks of the local community. Nowadays, there is less community engagement, with increased fragmentation between the social housing tenants, long-term owner occupiers and newly arrived gentrifiers. There is a relatively low level of community efficacy. Social housing tenants in particular lack a sense of empowerment, and doubt their capacity to effect change at community level. Furthermore, while many residents engage in informal social support networks, they lack trust in various institutions and are relatively disengaged from the political process. Kilmainham residents are concerned that the dilution of social capital (in the form of social networks with family and neighbours, community involvement and civic engagement) may weaken the community's capacity to sustain itself and undermine the social fabric of the neighbourhood. While communal bonds are still significant, there is a distinct lack of bridging and linking social capital in this neighbourhood.

\section{Conclusion}

The deep societal transformations that have come about in Italy and Ireland over the last $10-15$ years, are challenging the traditional effectiveness of the family-based welfare model for a number of reasons: family networks are changing, fewer families can rely on the assumption of a mother playing a full-time caring role, and a growing number of people pass through phases of the life cycle during which they cannot count on family help, or can do so only at the cost of familial tension and conflict. Here we have examined the differences and similarities between the two countries with respect to the articulation and diffusion of a social support 
model, and the latter's efficacy in the struggle against poverty. In doing so we focused on several domains: the welfare regimes in each country, the values underpinning civil society, and the nature and extent of mutual support networks in precarious neighbourhoods. In both countries there is considerable reliance on forms of informal social support as a way of supplementing income derived from welfare and/or low wage employment.

While family support has been found to be important across all social classes, we argue that it is more acutely so for those living in precarious neighbourhoods. Moreover support is predominantly moral and emotional rather than economic. Family also acts as a substitute for sociability in the precarious neighbourhood. Thus, social solidarity in the family is reinforced but at the expense of developing stronger civic bonds.

The conclusions should lead us to stress the similarities more than the dissimilarities between Aurora and Kilmainham. On the one hand, the communities in both neighbourhoods are inward-looking and perceive themselves to be somewhat distanced from the wider urban community. On the other hand, we observed a high degree of reliance on family and extended family networks for social support. In both cases segregation occurs because of ethnic diversification (and related feelings of fear), or simply because there is no longer a basis for shared class and cultural identity. Ties with neighbours are increasingly tenuous, and indirect ties, the type that create bridging and linking social capital, are limited.

There are also, however, some important differences between the two case studies. In Aurora the combination of low segregation, the prevalence of ethnic cleavages, the sense of not being included in urban renovation policies, the sense of being threatened by immigration and abandoned by society, lead the inhabitants to develop a culture of individualistic mobilisation, a weak attachment to the area, and a desire to leave even if they are unable to do so. In Kilmainham social segregation is particularly high, and primarily based on housing tenure. Those living in social housing have been beset by social problems which have had a deleterious impact on them, and on the adjoining (privately-owned) estates. Both groups feel somewhat under siege, and social support networks are relied upon to provide some respite. In the social housing complexes these social support networks have become extremely tenuous as stable families move out and are replaced by poorly resourced tenants. Even among the more the stable sectors of the neighbourhood social support networks are now coming under pressure from the process of gentrification. Gated communities encourage a more private lifestyle, and cut newer sections of the commuity off both physically and symbolically from the neighbourhood-at-large. 


\section{EUROPEAN SOCIETIES}

In Italy, the shortcomings of a welfare system based on subsidiarity are somewhat compensated for by familial social support networks. In Ireland, the welfare system has a more interventionist approach in relation to the family, and targets a range of supports at families who are deemed to be in need. But precarious families in Dublin are living in a far more socially segregated city than Turin. Thus, their reliance on social support networks remains crucial to counter the effects of living in neighbourhoods where social problems are spatially concentrated.

\section{References}

Bertaux, D., Boje, T. and McIntosh, S. (eds) (2002) Between Integration and Exclusion. A comparative Study in Local Dynamics of Precariousness and Resistance to Exclusion in Urban Contexts. Final Report. Denmark: Roskilde University

Bimbi, F. (a cura di) (2000) Le madri sole. Metafore della famiglia ed esclusione sociale, Roma: Carocci.

AQ1 Boje, T. and Halskov, T. (2001) Welfare State Regimes and the betmixt Countries...

Breen, R., et al. (1990) Understanding Modern Ireland, Dublin: Gill \& MacMillan.

Breen, R. and Whelan, C. T. (1992) From Ascription to Achievement? Origins, Education and Entry to the labour Force in the Republic of Ireland during the Twentieth Century, ESRI Working paper No. 39. Dublin: ESRI.

AQ2 Coleman, J. (1990) Foundations of social theory, Cambridge, MA.

Corcoran, M. P. (1998) Making Fatima a better place to live, Rialto, Dublin: Fatima Groups United.

Corcoran, M. P. (2002) 'Place attachment and community sentiment in marginalised neighbourhoods: A European case study', Canadian Journal of Urban Research 11 (1): 47-68.

CORI (2002) Conference of Religious in Ireland Justice Commission Briefing: Poverty, Low Pay and Social Welfare, Dublin: CORI.

AQ3 Daly, M. and Leonard, M. (2002) Against all Odds: Family life on low income in Ireland, Dublin: IPA and Combat Poverty Agency.

Dubet, F. (1995) 'Le figures dans la ville et la banlieu', Sociologie du Travail 2: $000-000$.

Duncan, G. and Paugam, S. (2000) 'The experience of Unemployment in Europe. The debate', in D. Gallie and S. Paugam (eds), Welfare Regimes and the Experience of Unemployment in Europe, Oxford University Press.

Eurostat (1997) 'Les responsabilités familiales comment sont elles partagées dans les ménages européens?', Statistiques en Bref 5. 
Fahey, T. (1999a) Social Housing in Ireland: A study of success, failure and lessons learned, Dublin: Oak Tree Press.

Fahey, T. (1999b) Poverty and Social Exclusion in Ireland. A Reviem of the Literature. Briefing document produced for BETWIXT project, Dublin: ESRI.

Fahey, T. (ed) (2000) Social Profile of neighbourhoods in seven European cities. BETWIXT Stage B report, Dublin: ESRI.

AQ4 Fischer (1982) To Dwell Among Friends. Personal Networks in Tomn and City, Chicago, IL: University of Chicago Press.

Flatley, J. and McIntosh, S. (eds) (2000) Social inequality and spatial segregation in seven european cities, London: London Research Centre.

Gray, J., Corcoran, M. P. and Peillon, M. (2003) 'Balancing family and work in a new Irish suburb', paper presented at the European Sociological Association Meeting, Murcia, Spain, September 2003.

Hirsh, B. and Jolly, A. (1984) 'Transitions and social networks. Social Support for Multiple roles', in V. Allen and E. Van de Vliert (eds), Role transitions. Explorations and explanations, New York: Plenum Press.

Hirshman, O. (1997) 'Conflitti sociali e società di mercato', in Idem., Autosovversione, Bologna: Il Mulino.

Irish Congress of Trade Unions (2002) Identifying Members' Childcare needs, Dublin: ICTU.

Ishii-Kuntz, M. and Seecombe, K. (1989) 'The impact of children upon social support networks throughout the life course', Journal of Marriage and the Family 51: 777-90.

Istat (1999) Rapporto sull' Italia, Bologna: Il Mulino.

Istat (2000) Rapporto sull' Italia, Bologna: Il Mulino.

AQ5 Istat (2002) Indagine trimestrale sulle forze di lavoro, Roma.

McKeown, K., Ferguson, H. and Rooney, D. (1998) Changing Fathers? Fatherhood and family life in modern Ireland, Cork: Collins Press.

McKeown, K., Pratschke, J. and Haase, T. (2003) Family mell-being: What makes a difference? Report to the Ceifin Centre, Shannon, Co. Clare.

Meo, A. (1999) 'Relazioni, reti e social support', Rassegna Italiana di Sociologia 1: 129-58.

AQ6 Meo, A. and Olagnero, M. (2000) 'Turin, little Aurora', in T. Fahey (ed.), Social profiles of neighbourhoods in seven European cities, Dublin, June.

Meo, A. and Olagnero, M. (2001) 'Living in precariousness in a postfordist town', in D. Bertaux (ed.), Households in precarity. Case histories from deprived neighbourhood in six European countries, Stage C Report of the BETWIXT research project, Paris, July.

Meo, A., Naldini, M. and Olagnero, M. (2001) Welfare in action: from virtuality to reality, Betwixt Project, Working Paper, Turin, June.

Miceli, R. (a cura di) (1999) Sicurezza e paura, IRES Working Papers 127. 


\section{EUROPEAN SOCIETIES}

Negri, N. and Saraceno, C. (ed) (1999) Il melfare municipale a Torino, Rapporto di ricerca, Dipartimento di Scienze Sociali, Università di Torino, Torino.

Negri, N. and Olagnero, M. (2001) 'Poveri e non poveri. I confini incerti dell'utenza di edilizia pubblica a Torino', in M.L. Bianco (a cura di), L'Italia delle diseguaglianze, Roma: Carocci.

NESF (2003) Report on Social Capital, Dublin: National Economic and Social Council.

Paugam, S. and Russell, H. (2000) 'The effects of employment precariousness and unemployment on social isolation', in D. Gallie and S. Paugam (eds), Welfare Regimes and the Experience of Unemployment in Europe, Oxford: Oxford University Press, pp. 243-64.

Pearlin, L. I. (1985) 'Social Structure and Processes of Social Support', in S. Cohen, D. Gallie, S. Paugam and L. Syme (eds), Social Support and Health, New York: Academic Press.

Peillon, M. (2001) Welfare in Ireland: actors, resources and strategies, Westport, CT: Praeger.

Perri, G. (1997) Escaping Poverty: from safety nets to networks of opportunity, London: Demos.

Pierce, G. R., Sarason, B. R. and Sarason, I. G. (1990) 'Integrating social support perspectives: Working models, personal relationships and situational factors', in S. Duck (ed.), Personal Relationships and Social Support, London: Sage.

Quarterly National Household Budget Survey - Childcare, Fourth Quarter (2002) Dublin: Central Statistics Office.

Report of the Commission on the Family - Executive Summary. (1998) Dublin: Department of Social, Community and Family Affairs.

Russell, H., Smyth, E., Lyons, M. and O'Connell, P. (2002) Getting out of the house: women returning to employment, education and training, Dublin: Liffey Press in association with the ESRI.

Saraceno, C. (ed) (2002) Social assistance dynamics in Europe, Bristol: Policy Press.

Saraceno, C. (2003) 'La conciliazione di responsabilità familiari e attività lavorative in Italia: paradossi ed equilibri imperfetti', Polis 2: 199-228.

Thoits, P. A. (1984) 'Explaining distributions of psychological vulnerability: Lack of social support in the face of life stress', in Social Forces 2: $453-81$.

Walker, M. E., Wasserman, S. and Wellman, B. (1993) 'Statistical models for social support networks', Sociological Methods and Research 1: 7198 .

Wall, K., Aboim, S., Cunha, V. and Vasconcelos, P. (2001) 'Families and information support networks in Portugal: the reproduction of inequality', Journal of European Social Policy 11 (3): 213-33. 
Wheaton, B. (1985) 'Models for the stress buffering functions of coping resources', Fournal of Health and Social Behavior 4: 352-64.

Wortman, C. B. and Dunkel-Schetter, C. (1987) 'Conceptual and methodological issues in the study of social support', in A. Baum and J. E. Singer (eds), Handbook of psychology and health, Hillsdale, NJ: Erlbaum.

Mary P. Corcoran is Senior Lecturer in Sociology. Her research interests include urban transformation and change. She has researched the social housing sector in Ireland, and is currently undertaking a study of social and civic life in the suburbs.

Antonella Meo is Professor of Sociology, Faculty of Political Sciences, University of Turin. Main fields of interest: poverty and social exclusion; vulnerability, inequality and family dynamics; coping strategies and stressful life events.

Manuela Olagnero is Associate professor of Sociology at the Faculty of Political Sciences of Turin. Member of the Italian Sociology Association. Consultant on urban renovation and housing policy for local organizations. Current research interests include: Longitudinal Analysis and "Life Course Research" applied to: family and housing trajectories, coping strategies of stressful life events, social outcomes of welfare policies in urban contexts.

Address for correspondence: Mary P. Corcoran, Department of Sociology, National University of Ireland, Maynooth, Co. Kildare, Ireland, Tel: 353-1708-3789, Fax: 353-1-708-3528,

Email: Mary.corcoran@may.ie

Antonella Meo, Department of Social Sciences, University of Turin, Via S. Ottavio 50 - 10124 Turin (Italy), Tel. 39-011-6702606, Fax. 30-0116702612,

E-mail: antonella.meo@unito.it

Manuela Olagnero, Dipartimento di Scienze Sociali, University of Turin, via S. Ottavio, 50, 10134, Torino, Italia, phone: office. 0039.011.6702680, fax: 00390116702612 ;

E-mail: manuela.olagnero@unito.it 


\section{AUTHOR'S QUERY SHEET}

Author(s): OLAGNERO, MEO \& CORCORAN reus 070103

Article title:

Article no:

Dear Author

Some questions have arisen during the preparation of your manuscript for typesetting. Please consider each of the following points below and make any corrections required in the proofs.

Please do not give answers to the questions on this sheet. All corrections should be made directly in the printed proofs.

AQ1 Boje and Halskov (2001) - full publication details needed.

AQ2 Coleman, J. - publisher?

AQ3 Daly, M. and Leonard, M. (2002) - pp. nos.?

AQ4 Fischer, (1982) - initial?

AQ5 Istat (2002) - publisher?

AQ6 Meo and Olagnero (2000) - publisher? 